\title{
The Politics of Memory: Constructing Heritage and Globalization in Havana, Cuba
}

GABRIEL FUENTES

Marywood University

Since granted world heritage status by the United Nations Educational, Scientific, and Cultural Organization (UNESCO) in 1982, Old Havana has been the site of contested heritage practices. Critics consider UNESCO's definition of the 143 hectare walled city center a discriminatory delineation strategy that primes the colonial core for tourist consumption at the expense of other parts of the city. To neatly bound Havana's collective memory / history within its "old" core, they say, is to museumize the city as "frozen in time," sharply distinguishing the "historic" from the "vernacular."

While many consider heritage practices to resist globalization, in Havana they embody a complex entanglement of global and local forces. The Soviet Union's collapse in 1991 triggered a crippling recession during what Fidel Castro called a "Special Period in a Time of Peace." In response, Castro redeveloped international tourism-long demonized by the Revolution as associated with capitalist "evils"-in order to capture the foreign currency needed to maintain the state's centralized economy. Paradoxically, the re-emergence of international tourism in socialist Cuba triggered similar inequalities found in pre-Revolutionary Havana: a dual-currency economy, government-owned retail (capturing U.S. dollars at the expense of Cuban Pesos), and zoning mechanisms to "protect" Cubanos from the "evils" of the tourism, hospitality, and leisure industries. Using the tropes of "heritage" and "identity," preservation practices fueled tourism while allocating the proceeds toward urban development, using capitalism to sustain socialism. This paper briefly traces the geopolitics of 20th century development in Havana, particularly in relation to tourism. It then analyzes tourism in relation to preservation / restoration practices in Old Havana using the Plaza Vieja (Old Square)-Old Havana's second oldest and most restored urban space-as a case study. In doing so, it exposes preservation / restoration as a dynamic and politically complex practice that operates across scales and ideologies, institutionalizing history and memory as an urban design and identity construction strategy. The paper ends with a discussion on the implications of such practices for a rapidly changing Cuba.

HERITAGE, DEVELOPMENT, AND TOURISM: A BRIEF HISTORY

While romanticized by the public, architects, and scholars alike as an urban jewel "frozen in time," Old Havana's value as a heritage object has been contested since at least the beginning of the 20th century. Emilio Roig de Leuchsenring, Havana's first City Historian, took on the task of preserving / restoring Old Havana as early as 1935-24 years before the 1959 Cuban Revolution. Yet despite his efforts to protect Old Havana from ruin (designating it as a "protected zone" in 1945), he got very few preservation / restoration projects off the ground during his tenure. In 1967, Eusebio Leal Spengler (Roig's assistant) was promoted to Historiador de la Ciudada de La Habana (City Historian of Havana) and was tasked with advocating for an old urban core that was by then facing major shifts in demographics, deteriorating infrastructure, and waning public perception.

By the 1980s, Old Havana - crumbling under the effects of economic centralization, crime, salt, humidity, water, and government neglectappeared a different city than its old republican self. To add, both the revolutionary government and the Cuban public associated the dilapidated urban fabric with the ills of capitalism, prompting Leal to double-down on his rehabilitation efforts. His first project was to restore the Palacio de los Capitanes Generales, which would ultimately become the Museum of Havana. The international attention gained by that project helped Leal establish international partnerships to aid in restoration / preservation process; in 1976 the Cuban Ministry of Culture partnered with the United Nations Development program to 
raise $\$ 1$ million U.S. dollars ( $\$ 200,000$ a year over a five-year period) to help establish the Centro Nacional de Conservación, Restauración y Museología (National Center of Conservation, Restoration, and Museology). Following the establishment of this agency, the National Assembly of State passed two acts calling for the protection of cultural heritage.

Despite the success of Leal's early work, however, the revolutionary government stood opposed to using resources to rehabilitate of the old urban core-focusing instead on building factories and developing housing in the rural outskirts of the city. Of course, the effects of this social "leveling" project left Old Havana's 74,000 residents to live in extreme poverty and squalor. Yet ill will towards urban development and real estate speculation left its fabric-its scale, dimensions, proportions, contrasts, continuities, solid/void relationships, rhythms, public spaces, and landscapes-intact, albeit in poor condition. Finally, after drafting a five-year plan to restore Old Havana in 1981, Leal convinced the government to pledge $\$ 10$ million, to which UNESCO added $\$ 200,000$. By 1982 , Old Havana-delineated as the 143 hectare geographic area defined by the old city walls, including its 4,000 buildings (900 of which are considered "masterpieces")-was designated a world heritage site, with all of its geopolitical implications. With new international support, the Office of the City Historian drafted comprehensive restoration plans for the old core, starting with its major plazas (including the Plaza Vieja, which I will also discuss later on) and principal streets. Restoration was underway until the Cuban government's ability to fund the work was disrupted by the economic crisis following the collapse of the Soviet Union, their strongest ideological and economic ally at the time. ${ }^{1}$ Hence before teasing out the historical and theoretical complexities of heritage construction as such, it is important to contextualize the restoration / preservation of Old Havana within a geopolitical framework that pulls together Cuba's global instability, its revolutionary ambitions, its socio-economic development, and its shifting positions on international capital and tourism.

Pre-Revolutionary Havana. After the second Spanish-AmericanCuban war (1866-1898), U.S. political and economic interests in Cuba intensified due largely to the sugar and real estate industries. By the 1920s, Cuba's economy-benefitting from the sudden return of Cuban capital to the island, most of which was held in U.S. during the war-soared, triggering the so-called vacas gorda (fat-cow) period and an intense building boom that, typical of capitalist development, responded more to the market logics of real estate development and land speculation than to the professional knowledge and sociocultural responsiveness of architects and urban planners. According to Mario Coyula, "Many master plans for the city were put forth, including those by Raul Otero (1905), Camilo Garcia de Castro (1916), Walfrido de Fuentes (1916), and Pedro Martinez Inclán (1919). ${ }^{2} \mathrm{He}$ continues: "these plans were rendered defenseless against crude land speculation by landowners who held onto large tracts of land or sold them off in piecemeal fashion (to the highest bidder). ${ }^{13}$

Hence as Havana expanded, it did so along developmental axes that were not always in the best interest of the old core's "sense of place."
With a widening range of political and economic actors and stakeholders in the mix (e.g. foreign and local banks, insurance companies, investors, developers, etc.), it was not long before a series of faceless, banal, and over-scaled "Modern" buildings broke through its low colonial skyline, sprinkling the city with overt symbols of western wealth and political / economic power; new banks and a stock exchange, for example, formed a "mini Wall Street" area in the center of the old core. As Havana's population more than doubled by 1929 , due in part to new political and economic influences, developers looked west toward the "open" periphery searching for new development opportunities. Eventually, Havana would expand (read: sprawl) beyond its old city walls into a series of high-end Garden City-type neighborhoods linked by lusciously landscaped calzadas.

Havana's western expansion, of course, required a considerable amount of financial and infrastructural investment. To help guide its transformation into a modern metropolis, the U.S. (which by the 1930s had considerable political and economic interest in Cuba) initiated and funded several major public works projects; namely, an expanded network of water mains, streetlights, communications, natural gas, and street improvements as well as a comprehensive system of sewage and garbage collection. As a major economic engine, international tourism played a major role in this expansion strategy: both public and private stakeholders recognized the political and economic value of connecting the old core to the newly developed suburbs. Leveraging scientific advancements in building materials, the U.S. Corp of Engineers designed the Malecon-a five-mile long, four-lane highway and seaside promenade at the coast of the city (first proposed by the engineer Francisco de Albear in 1874)-in 1901, the first phase of which was built in 1902 and was fully completed in 1952. Political ideology notwithstanding, the Malecon, while a heavy-handed, economicallydriven project, was a smart urban development strategy: as Havana's new "public living room," it not only mitigated the negative environmental effects of increased automobile usage, but also embellished the city with a continuous waterfront edge that mesmerized visitors as it filtered them slowly into the increasingly tourist-friendly historic core. It remains one of Havana's most vibrant, profitable, and beautiful urban spaces.

Of course, U.S. aid and development would come at a price. Following the war, U.S. interests monopolized urban services, agriculture, and the tourist industries - triggering rapid and uneven development. Following the vacas flacas (lean-cow) period triggered by the economic crisis of 1920 (which forced many Cuban and Spanish firms into bankruptcy) U.S. businesses quickly increased investment and production in Cuba at such a rate that by 1925 , Havana had become all but subservient to American economic interests-exporting $50 \%$ of its sugar to the U.S. Eventually, the U.S would control $50 \%$ of the city's railroads, $40 \%$ of its sugar production and $90 \%$ of its telephones and electric utilities as well as $25 \%$ of all bank deposits. ${ }^{4}$ Meanwhile, the Cuban government continued to invest borrowed money toward modernizing Havana; falling deeper into debt and more entangled with U.S. economic interests.

By the 1950s, Havana was a bustling city fully absorbed in the effects of Vegas-style capitalism; the growth of the financial, gambling, 


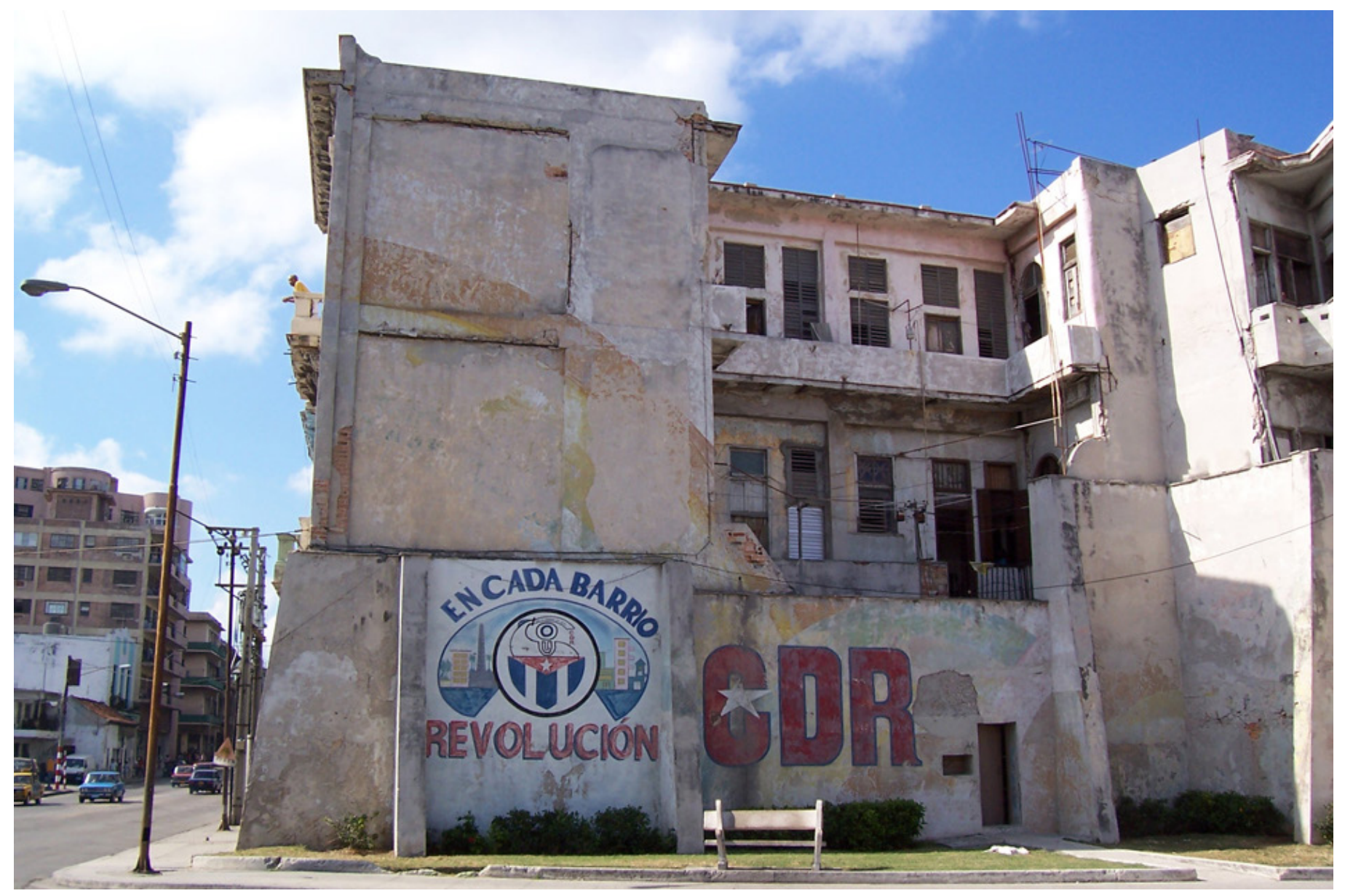

Figure 1: "In every neighborhood, Revolution! Dilapidated building in Central Havana, Photo by Author, 2004.

and tourism markets bred all sorts of crime, inequality, and corruption. Notorious mobsters such as Meyer Lansky and Charles "Lucky" Luciano operated profitable crime rings; crime "families" controlled virtually all gambling, narcotics, and prostitution in Havana with the support of Fulgencio Batista's government (explicitly and/or implicitly). Indeed Havana was being marketed and consumed as a tourist playground, where one could leave behind all sorts of illicit activities on their half-hour flight back to Miami. Henry Louis Taylor Jr. and Linda McGlynn put it this way,

"Prior to the revolution, the U.S. mafia controlled the international tourist industry in Cuba and anchored it in gambling, prostitution, and drugs along with the attractions of the sun, sea and sand. Tourism was about pleasure and thousands of visitors from the United States and around the world came in search of it. Between 1948 and 1957, tourists arrivals in Cuba grew by 94\%... arrivals from the USA alone accounted for approximately $86 \% .{ }^{115}$

They continue,

"However, tourism and sugar painted Havana's social landscape in misery and pain. There were more that 5000 beggars walking the streets of the city in 1958, many of whom were homeless women with children. Crime was on the rise and so too was juvenile delinquency. Arthur Schlesinger Jr. recalled a visit to Havana during the Batista epoch: "I was enchanted by Havana-and appalled by the way that lovely city was being debased into a great casino and brothel for American businessmen over for a big weekend from Miami. My fellow countrymen reeled through the streets, picking up 14-year-old Cuban girls and tossing coins to make men scramble in the gutters. One wondered how any Cuban-on the basis of this evidence-could regard the United States with anything but hatred."

Revolutionary Havana. Hence in January of 1959, Fidel Castro and his militia ousted President Fulgencio Batista and inherited a Cuba whose development was severely compromised by a single-crop (sugar), singleexport (U.S.) economy. As Coyula states, "Profit and land speculation drove development. Little concern was given to the quality of the natural environment, the rational use of human and material resources, or social and spatial segregation." In response, los rebeldes (the rebels) sought to "level out" the social strata-to construct what Che Guevara defined as a "new" man within "new" society-by focusing development on peoplecentered, socialist conceptions of justice, reciprocity, and equity.

Hence the new leadership established development strategies that focused more resources to the underdeveloped rural outskirts than to Havana, by now associated with both the bourgeois culture of uncontrolled capitalism and an oppressive colonial past that the revolution was all too happy to erase. In effect, by ruralizing the city and urbanizing the countryside, development in revolutionary Cuba 
focused on flattening the spatial concentration and redistributing the social inequalities triggered by its capitalist predecessors. To add, Cuba's increasing financial dependence on and ideological adoption of Soviet political, economic, and social development models formed an international, anti-American partnership that flourished until the USSR and the Eastern European Communist Bloc collapsed in 1989. In retaliation for nationalizing U.S. businesses and properties, the United States imposed a crippling commercial and economic embargo against Cuba in 1962 that is still in place today (2016).

As intended, the U.S. embargo, layered onto the anti-urban, Sovietinfluenced development strategies already in place since the revolution's coup, have severely stalled architectural and urban development in Havana. To add, the very idea of preserving / restoring the "old" Havana was anathema to the "future-oriented" Socialist ideals of the new polity, which sought to sever any ties with its colonial past. Hence if the old system emphasized international tourism-long believed by the revolution to be associated with capitalist evils (drugs, prostitution, racism, corruption, social inequity, etc.) and U.S. imperialism - as a way to leverage and mitigate the effects of globalization, the new system focused on domestic tourism as a way of inculcating national pride, as a form of pedagogical leisure time designed to emphasize the leftist idea that all of Cuba belonged to all Cubanos. To this extent, the revolutionary government established the Instituto Nacional de la Industria Turística (The National Institute of the Tourism Industry or INTUR) in November of 1959, a mere 10 months after Castro's coup.

This had a profound effect on the way public spaces were used in the city, particularly during the early years of the revolution. In contrast to republican-era capitalist urban space-privatized, commoditized, and slated for consumption-socialist public spaces were politically charged and set the stage for the collective vision of socialism to unfold within the city. In other words, such spaces were used to discipline the public in socialist values and ideals rather than as a conduit for market forces. Hence what was once La Plaza Cívica (Civic Plaza) became La Plaza de la Revolución (Revolution Square), repurposed to host massive socialist parades and gatherings. To add, centralized planning made little room for competition and private enterprise, resulting in basic resources including food, fuel, and income being evenly rationed from the top down. As a result, automobile usage decreased and, as the U.S. tightened their trade embargo, public transportation and bicycles became the dominant mode of transportation. By the late 1960s, banal Soviet-style housing blocks, monuments, and technical institutes-spaces of collective work and socialist ceremony-coexisted with the capitalist relics of pre-revolutionary eras. Yet despite the dreary physical development, Cuba did make major advancements in social development, namely in education, the sciences, and medicine.

But after the 1991 Soviet collapse, Cuba lost almost $75 \%$ of its international trade, leaving its economy in shambles and triggering what Fidel Castro called the "Special Period in a Time of Peace." In response, the revolutionary government redeveloped international tourism in order to capture the foreign currency needed to maintain its political, economic, and social structures. Castro explained, "We have to develop tourism. It is an important source of foreign currency. We do not like tourism but it has become an economic necessity." Interestingly, international tourism within a socialist framework triggered inequalities similar to those found in pre-revolutionary Havana. The legalization of the U.S. dollar-and, of course, the governmentowned retail stores designed to capture it-along with naïve policies and strategies to separate Cubanos (read: "protect" them) from the so-called evils of the tourism, hospitality, and leisure industries triggered a dual-society / economy that marginalized local Habaneros while catering to wealthy foreign consumers. In effect, tourism-and as I will discuss soon-restoration/preservation - encodes aesthetic demarcations onto the Havana's urban, economic, and social fabric.

\section{HERITAGE TIME-FRAMES}

The construction of cultural heritage unfolds as a negotiation between narrated histories, collective memories, and contested authenticities, often in a context of power and national Identity. In other words, as power relations and national identities shift (as they certainly have in the Cuban context), the meaning and agency of history, memory, and authenticity shift with them. Seen this way, heritage is not embedded into artifacts, but rather projected onto them.

Between Constructed Histories and Collective Memories. While counter-productive as a trope for the city, to be a monument "frozen in time" has roots in Modern preservation theory. Since the Enlightenment, preservation discourse and practice (along with Western architectural theory) has been entangled with questions of 'progress' and Modernity; for if the Modern stood opposite to a "traditional" past, then to preserve that past was to enclose "tradition" (those ills of the "premodern" world) and distance it away through the teleological progress of a Modernity purified through Reason. Hence preservation not only established a historical ground against which to legitimate the Modern but also helped distinguish a time before Modernity from a time after it-relegating historic monuments to the former in order to help construct the latter. In Hegelian fashion, then, the preserved monument stood frozen in time somewhere in between the end of tradition and the beginning of Modernity.

Inherent in modernization processes, then, are questions regarding preservation value: By what concrete criteria are things included/ excluded in the preservation frame? What artifacts and events are worth preserving? How is history assigned value? What makes a monument? In "Preservation and Modernity: Competing Perspectives, Contested Histories and Questions of Authenticity," Mrinalini Rajagopalan analyzes historic preservation as a political practice (the construction of Modernity was indeed political) in relation to forces of colonization, nationalism, post-modernity, and globalization. ${ }^{9}$ By her account, historic preservation can never be separated from its affiliations with power; for if the colonial city used preservation to encode difference onto indigenous pasts, contemporary heritage institutions (UNESCO, ICOMOS, etc.) homogenize aspects of such pasts by standardizing the meaning of heritage across the globe.

Situating historic preservation within discourses of modernity and 
modernization exposes inherent paradoxes: as a heritage-building practice, historic preservation entangles narrated histories and embodied memories to bring the past in and out of view (forgetting is the other side of remembering). By simultaneously constructing and erasing histories, the preservation frame renders heritage objects both timeless and contemporary-foregrounding and backgrounding the past relative to the present while crafting and instrumentalizing collective memory for political gain. For while historic preservation attempts to freeze time to a particular moment of universal historical "truth", the collective memory it bounds and historicizes is both produced in the shared social spaces of everyday life and embedded in contemporary power relations, often in a context of nationalism.

Seen this way, memory is not embodied in artifacts but are attached to them through social processes of signification. In her article Collective Memory Under Siege: The Case of 'Heritage Terrorism', M. Christine Boyer takes issue with those who represent memory-collective or otherwise-is an objective thing in itself outside of social and political practice. In other words, for Boyer, memory is not some withdrawn condition waiting to be activated or released from the urban fabric but is rather socially produced and constituted in discourse as a "storehouse for memories. ${ }^{10}$ Heritage objects, then, are the anchoring points for such discourse, the points around which collective memory is gathered, recollected, and/or instrumentalized, often in political contexts.

Heritage value, then is both acquired and projected (not, as already mentioned, embodied). In his seminal 1903 essay "The Modern Cult of Monuments: Its Character and Its Origin," philosopher and art historian Alois Riegl theorized monuments as "a human creation, erected for a specific purpose of keeping single human deeds or events alive in the minds of future generations. ${ }^{111}$ For Riegl, there were two types of monuments: 1) intentional monuments: those built specifically to commemorate specific historic periods and events, and 2) unintentional monuments: those, that while built without such commemoration intent, acquire historic value as through age. While useful, both types are defined using very different logics. Whereas the former attempts to disrupt time and distance-that is, to reference and represent the past in the present as a way of evoking and immortalizing a specific memory of that history - the latter attempts to preserve time and distance; that is, to reveal its age-the traces of its "authenticity." Hence it can be argued that any process of urban / architectural restoration attempts to convert unintentional monuments to intentional ones.

\section{HERITAGE PLACE-SCALES}

"On an international plane, UNESCO's discourse about places like (Old Havana) reterritorializes by disembedding sites from their concrete locations within the boundaries of local, regional, and national meanings and policies, and reattaching them to UNESCO's World Heritage program and its notions of "universal cultural value."_Matthew J. Hill12

Contemporary heritage construction is a multi-scalar project that involves the reorganization of a range of social and institutional relationships that intersect at various geographic and political scales. UNESCO-established in the immediate postwar context (1945) in part to carry out the CIAM's Athens Charter mandate to preserve historic urban fabrics-constructs heritage through a dialectical process of deterritorialization and reterritorialization by (dis)articulating geopolitical relationships between and among local, national, and planetary scales in order to align specific national identities with a "universal history of mankind." In this way, UNESCO situates local heritage objects (historic cities, sites, buildings, and artifacts) within the global flows of capitalist expansion, international capital, information technology, and tourism (and vice versa) - looping them together with its global heritage grid, that geographic space of "outstanding universal significance." Seen this way, heritage is but the other side of globalization; to understand historic preservation as a heritagebuilding project is to understand the ways in which UNESCO's global project loops (and scales) through local processes of (re)constructing sites as cultural patrimony, processes embodied in the multiple (and at times competing) interests of specific actors and their institutions.

Hence in Old Havana, historic preservation practices pull UNESCO's universal cultural project, Cuba's quasi-socialist political project, and the city's heritage project into each other as they all negotiate the meaning and value of cultural patrimony; for if UNESCO redraws the world's cultural and natural heritage in its own image, in Old Havana this image is infused with the ideals and development practices of a nation-state that seeks consumption and tourism to survive. Cuba's political/ideological project, in turn, intersects with multiple actors on the ground (architects, urban planners, preservationists and politicians on the one hand, the hospitality industry, entrepreneurs, and tourism developers on the other) who participate in "the work of bounding, naming, marking, and regulating the urban landscape so that it can be known and recognized as an 'authentic' heritage object. $^{\prime \prime 3}$ The institution that binds these actors together is the Office of the City Historian (hereafter $\mathrm{OCH}$ ).

The Office of the City Historian. In 1993, British reporter Jonathan Glancey toured Old Havana with a Cuban conservationist Victor Marín when the UNESCO-designated Colegio Santo Angel collapsed. In an article for The Independent on October 19, 1993, he wrote:

"To say that Havana is collapsing is to state the obvious. It is even more obvious when the building you are about to enter falls down in front of you. One moment Victor Marin, one of the city's leading architectural conservationists, is reciting the faded glories of the arcaded 18th century merchant's house that occupies the northwest corner of Plaza Vieja, one of the oldest and most elegant squares in the Americas. The next, the building crumbles and falls as quickly and quietly as a house of cards. ${ }^{\text {"n4 }}$

After this article along with images of the collapse spread across European media, President Fidel Castro purportedly met with City Historian Eusebio Leal to discuss restoration strategies in Old Havana. Well aware of the economic constraints of such efforts, Leal suggested a hybrid capitalist-socialist strategy: if granted control over state-owned hotels and restaurants, he would use (some of) the profits toward restoration projects in Havana. Soon after, Cuba's Council of State passed Law Decree 143, transforming the OCH into a 


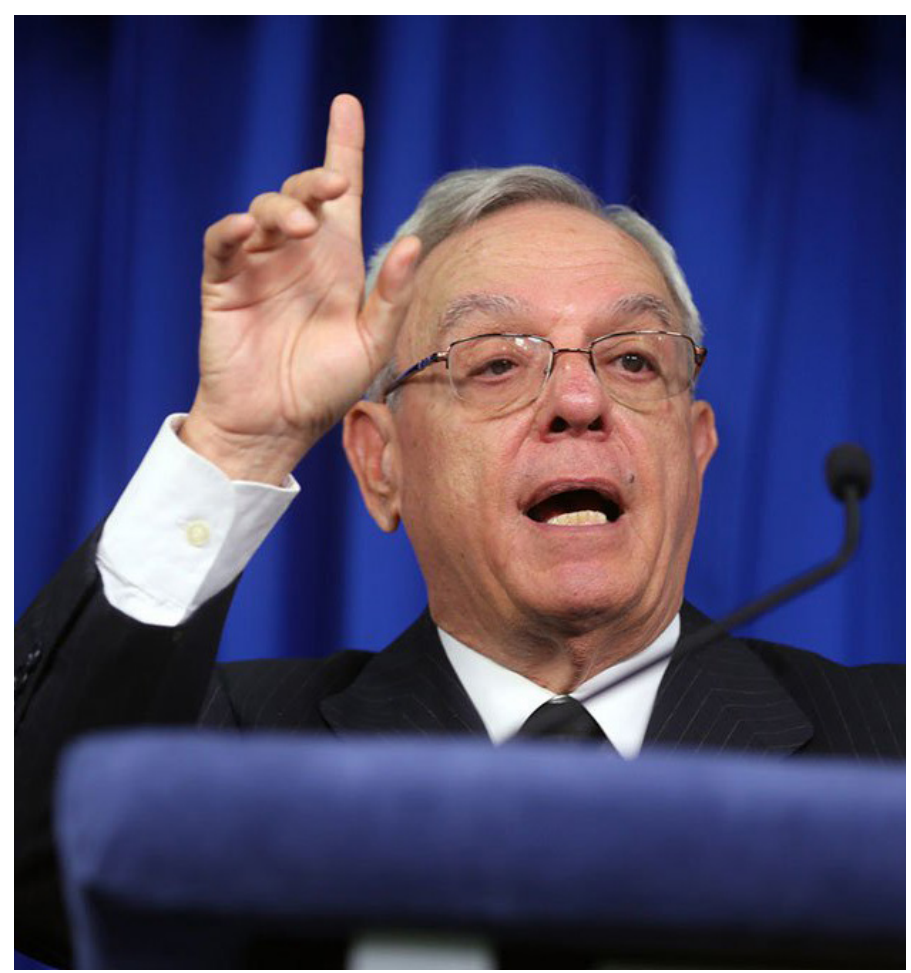

Figure 2: Eusebio Leal Spengler, Hanava City Historian. Image Credit: Digital Hoy, August 6, 2015

decentralized, autonomous, and self-financed institution with the power not only to rezone and redevelop sites in the historic district, but also to tax those operating in it. In short, the $\mathrm{OCH}$ was granted absolute authority over every public investment in the historic zone (zoning, housing, public administration, financial management, etc.) as well as authority to negotiate directly with foreign investors and run businesses for-profit (hotels, restaurants, museums, real estate deals, etc.) in order to promote the "physical and social" restoration of Old Havana. Starting with $\$ 10,000$, the $\mathrm{OCH}$ now generates over $\$ 80$ million under its own profit-making enterprise, Habaguanex S.A., with Leal himself as CEO.

In 1994, the OCH and Habaguanex S.A. formed a group of architects and planners to master-plan the UNESCO-defined area including Old Havana, Central Havana, and the Malecón-Havana's seaside promenade. The plan claims to "preserve the historical patrimony of the city, address urban problems, and promote responsible community and urban development." 1 Their strategy was to implement a "Special Plan for Integrated Development," which defines a "Priority Zone for Preservation and Highly Significant Zone for Tourism. "16 On the relationship between tourism and preservation, Leal writes,

"Tourism has double significance. It provides an opening to the world, a chance to hear other voices, to break down insulation and the blockade. Tourism draws us closer to other people, to other forms of living, dressing, thinking and feeling, and that is good. Its second significance is economic: tourism is an indispensable part of our economic strategy and is important to the country. We must reconcile tourism with the preservation of the city. We must respect Cuban ecology and Cuban history, and the development of tourism must work within this context." 17

In theory, the plan develops tourism through preservation / restoration of the historic core and uses the revenue for urban and social development projects throughout the city-in effect using capitalism to sustain socialism. In practice, however, the plan narrowly frames and defines fragments of the city as "historic" and marginalizes the majority of Cubanos both socially and economically.

Working within a significantly autonomous fiscal and political framework, Habaguanex is Havana's most productive developer and memory machine-linking historic preservation/restoration projects directly with the construction of dollar-generating bars, hotels, and restaurants. In an effort to preserve "social and spatial balance" (read: generate the most tourist dollars), Habaguanex strategically focused on restoring and preserving the dilapidated buildings and sites along Calle Obispo, Paseo del Prado, and Old Havana's four major plazas: Plaza de San Francisco, Plaza Vieja, Plaza de la Catedral, and Plaza de Armas-priming these for tourist consumption along a neatly bound geographic network of heritage sites. In the process, Habaguanex formed international partnerships, often working on specific projects with European investors and non-profit preservation institutions. As foreign investors invested more capital into tourism, Cuba-perhaps unwittingly_invested more "human resources" to its growing memory machine; In 1995, Cuba's Council of State passed Law Decree 77, mandating that Cuban hospitality workers be paid with national currency instead of the Convertible Peso, a law that in effect not only situated local Cubanos outside of the preservation frame (is their livelihood not preservable?), but also commodified both their labor and everyday lives.

Still, while reopening itself to the international tourism and the global economy, Cuba maintained majority control over restoration / preservation. By 1996, Habaguanex had transformed the former Lonja del Comercio building into a new \$13 million office complex jointly financed with a Spanish firm. They had also begun restoration work on the Plaza Vieja.

\section{CASE STUDIES}

Plaza Vieja. Built in 1559, the Plaza Vieja was traditionally used domestically for recreation and commercial purposes (markets, parties, etc.) at a time when the city's only other public square-the military-occupied Plaza de Armas-was used exclusively for civic and defense purposes. Bound by San Ignacio, Mercaderes, Teniente Rey, and Muralla Streets, the plaza was originally named the Plaza Nueva until 1835 when it was renamed Plaza Vieja in order to distinguish it from the new Plaza de Cristo. But its name was not the only thing changed. With its renaming also came a fundamental change in use after Governor Tacon built the central Mercado de Cristina, resulting in the gradual transformation of the square both programmatically and geometrically until 1908 when the market building was destroyed. Then in 1952 the plaza underwent another major transformation: an increasing amount of cars linking the Malecon to the historic core prompted the city to commission a public parking garage 


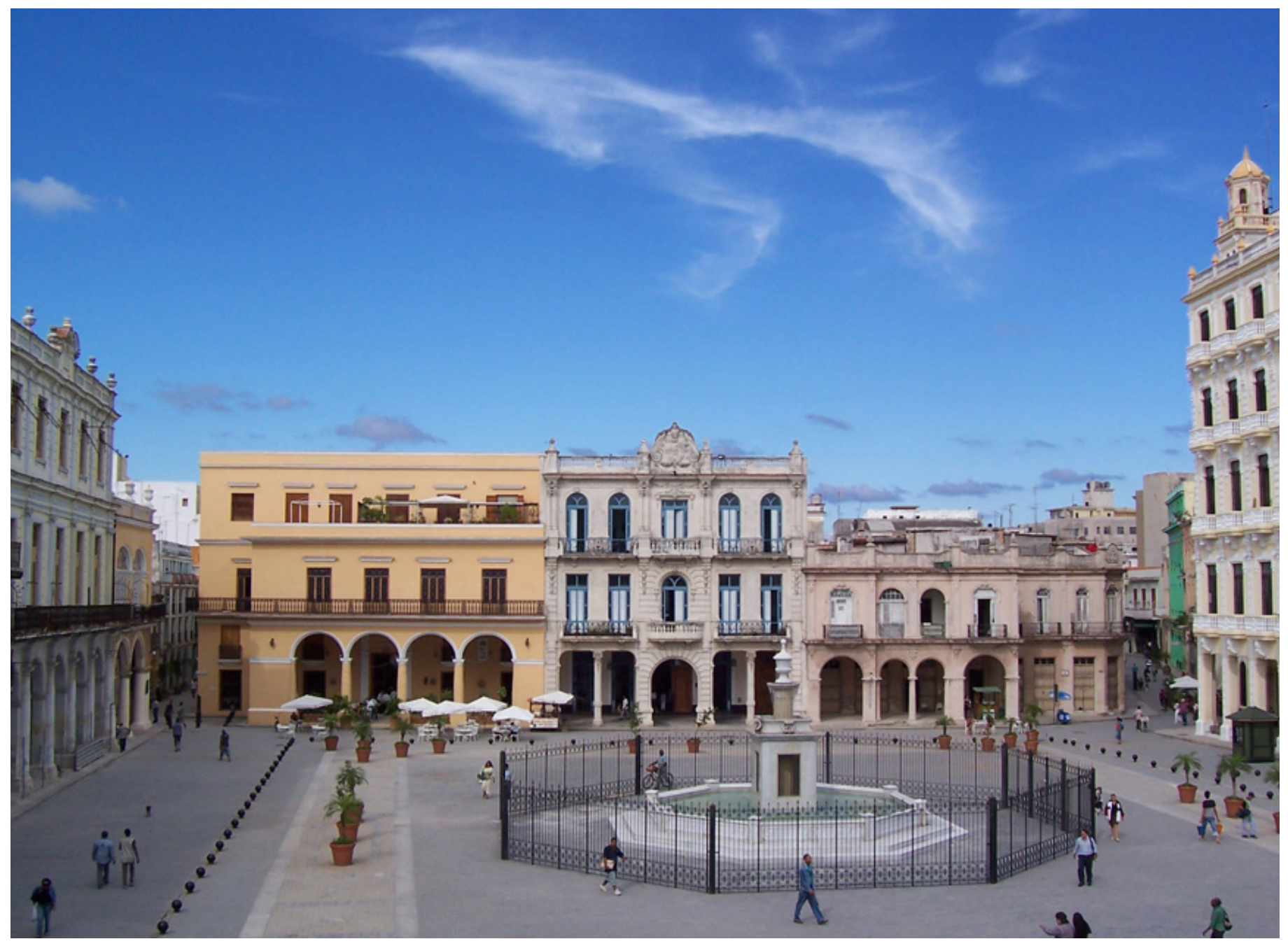

Figure 3: A Restored Plaza Vieja fit for tourism. Photo by Author, 2004.

to accommodate the "bulky American autos." Designed by modern architect Eugenio Batista, that partially sunken structure defined the plaza's central space for the next 46 years until it was demolished in 1998.

When the demolition crews arrived to the plaza in 1996, they had planned to implode the parking garage with explosives, effectively eradicating any trace of the republican-era structure and the "modernist" park that sat a meter off the ground on its roof-top surface. The Havana Park, as it was known locally by Habaneros, was valued as a public urban space: it included trees, benches, a large amphitheater, and open green spaces used by residents to gather, listen to music, drink rum, dance, ride their bikes, debate baseball, and enjoy the Caribbean breeze from the harbor. It was, for better or worse, a true community space, one that framed, enabled, and intensified everyday urban life.

But the everyday urban life of this community would indeed be disrupted for the next two years as demolition crews slowly chipped away 235 tons of concrete with jackhammers, a compromise in the demolition method made after residents protested to the Communist Party fearing that imploding the garage with explosives would risk damaging and/or collapsing their vulnerable tenement buildings surrounding the plaza. When it was all said and done, all that was left was a gaping hole in the plaza's center, a temporary scar of a recent republican past that was all but violently erased. In its place, conservationists restored the plaza to street level by dressing the imported topsoil with polished stone paving and-no doubt to regain that old "colonial charm"-placing a large imported Italian marble fountain in the center protected by a ten-foot-high black iron fence meant to prevent neighborhood kids from bathing in its waters and to set up the spatial relationships necessary for tourist gaze consumption, relationships predicated on strategic distancing (between subject and object) and the selective (re)bounding, (re)positioning, and (re)narrating of such spaces and objects in order to assert heritage-value. Removing the garage, repaving the plaza, and installing the fountain was only the beginning of a large-scale, long-term preservation / restoration strategy aimed at transforming the plaza form a public urban space to a commodified tourist spectacle. Consider the interventions that followed, as described by anthropologist Matthew J. Hill:

"First, conservationists mounted a camera obscura on the roof of the plaza's tallest building, through which tourists are afforded a panorama of the plaza. Next, they opened the restored balconies of former palaces transformed from tenements into hotels, 
museums, and shops, offering the tourist another set of viewing points from which to gaze down upon the square. Further, they mounted a large placard at the main entrance to the square, depicting enlarged reproductions of various eighteenth-century engravings of the square by different European traveler artists, and set in place life-sized cutouts of Spanish colonial troops dressed in signature red-and-white uniforms, playing fife and drums. Finally, viewers to this space are instructed in how to see it as part of a "disciplined order of things" by tour guides who circumambulate through the square, instructing viewers what to see and how to see it."18

Such design strategies produce heritage space not only by simply restoring colonial features but also by selectively highlighting the historic elements that cast the plaza's colonial past; that is, in order to reveal a specific colonial history, such preservation / restoration practices must also conceal cultures, events, histories, and features that don't fit neatly into the colonial heritage framework. The newly "restored" Plaza Vieja, for example, comes equipped with all sorts of defense mechanisms against potential defilements: ranging from the heavy metal cannons and chains installed at the four corner entries, to the security features placed in lieu of widely used public benches, to the uniformed police officers that, fearing the onslaught of kids, prostitutes, thieves, hustlers, and flaneurs, discourage all local Cubanos from loitering and mingling with tourists, to the banning of Rumba-a form of percussive Afro-Cuban music that is linked to the lower tenement classes-from the plaza's bars and restaurants.

\section{CONCLUSION}

As we have seen, preservation and conservation in / of Old Havana involves spatial practices that intertwine the influences and ambitions of multiple actors and stakeholders across geographic, political, and economic landscapes-in effect globalizing the local by re-territorializing "historic" fragments of the city within UNESCO's "world heritage" framework.

Concurrently, while UNESCO defines the criteria for sites of "outstanding universal value," local actors in Old Havana $(\mathrm{OCH}$, architects, urban planners, conservationists, and politicians) take measures to localize UNESCO's "world heritage grid" within Old Havana's geographic boundaries; that is, they "do the work of bounding, naming, marking, and regulating the urban landscape so that it can be known and recognized as an 'authentic' heritage object. ${ }^{\text {"19 In }}$ the process, administrative measures are taken to ensure that local sites adopt the transnational language of UNESCO-standardizing the historic core's urban space according to their specific rules, procedures, and regulations.

By this definition, the "Special Plan for Integrated Development" is not very "integrated." To clarify, the issue is not preserving / conserving Havana's historic core as such but the inequalities triggered by the spatial / heritage practices deployed, practices that frame specific parts of the city as objects of consumption at the expense of broader social and urban concerns. In other words, the "reterritorialization" process-and the "world heritage" status it produces-excludes the vast majority of Cubanos from the tourist flows it sets up. And while claiming to address the city as a whole, "heritage sites" in Old Havana exclude elements and histories that are not fit for such consumption; that is, they are limited to the "monumental political, military, ecclesiastical, and residential architecture of what one conservationist called eighteenth and nineteenth-century 'palace Havana' "while excluding other vernacular elements important to Havana's urban history (tenements, docks, warehouses, red-light districts, industrial buildings, etc.). ${ }^{20} \mathrm{OCH}$ 's plan treats Old Havana as a museum object for the tourist gaze, "a city frozen in time."

\section{ENDNOTES}

1. For a more comprehensive study on the relationship between preservation and tourism, see: Stamm, Lauren. "Deconstructing the Dual City: Preservation and Tourism in La Habana Vieja." (2014).

2. Scarpaci, Joseph L., Roberto Segre, and Mario Coyula. Havana: Two faces of the Antillean metropolis. UNC Press Books, 2002.

3. Ibid.

4. Ibid.

5. Taylor, Henry Louis, and Linda McGlynn. "International tourism in Cuba: Can capitalism be used to save socialism?." Futures 41, no. 6 (2009): 405-413.

6. Ibid.

7. Scarpaci, Joseph L., Roberto Segre, and Mario Coyula. Havana: Two faces of the Antillean metropolis. UNC Press Books, 2002.

8. Taylor, Henry Louis, and Linda McGlynn. "International tourism in Cuba: Can capitalism be used to save socialism?." Futures 41, no. 6 (2009): 405-413.

9. Rajagopalan, Mrinalini. "Preservation and Modernity: Competing Perspectives, Contested Histories and the Question of Authenticity." The SAGE Handbook of Architectural Theory (2012): 308.

10. Boyer, Christine. Collective Memory under Siege: The Case of 'Heritage Terrorism,'. London: SAGE Publications, 2012.

11. Riegl, Alois. "The modern cult of monuments: its character and its origin." Oppositions 25 (1982): 20-51.

12. Hill, Matthew I. "Reimagining Old Havana." Deciphering the global: its scales, spaces and subjects (2007): 59.

13. Ibid.

14. Glancey, Jonathan . "Walls came tumbling down." The Independent, October 19, 1993.

15. para la Revitalización Integral, Plan Maestro. "de La Habana Vieja.(2011)." PEDI Plan Especial de Desarrollo Integral: 37.

16. Ibid.

17. Ibid.

18. Hill, Matthew. "The Future of the Past: World Heritage, National Identity, and Urban Centrality in Late Socialist Cuba." Global Downtowns. Marina Peterson and Gary McDonogh, eds (2012): 186-206.

19. Hill, Matthew I. "Reimagining Old Havana." Deciphering the global: its scales, spaces and subjects (2007): 59.

20. Ibid 